\section{Crop Nitrogen Status Assessment Tools in a Decision Support System for Nitrogen Fertilization Management of Potato Crops}

\author{
Jean-Pierre Goffart ${ }^{1}$, Marguerite Olivier, and Marc Frankinet
}

ADDITIONAL INDEX WORDS. Solanum tuberosum, petiole sap nitrate concentration, leaf chlorophyll index, canopy reflectance, leaf chlorophyll fluorescence, remote sensing

Summary. A decision support system (DSS) was based on the splitting of total nitrogen $(\mathrm{N})$ fertilizer application combined with in-season assessments of crop $\mathbf{N}$ requirements aimed to matching, at field scale, potato (Solanum tuberosum) total crop $\mathrm{N}$ requirements and mineral $\mathrm{N}$ supply from soil and fertilizers. After the preplanting establishment of the total $\mathrm{N}$ recommendation based on the predictive balance-sheet method at a specific field scale, $70 \%$ of the recommended amount was applied to the crop at planting. Subsequently, at 20-50 days after emergence (DAE) the need for supplemental $\mathrm{N}$ was assessed through noninvasive measurements of leaf chlorophyll concentration directly in the field. A simple conditional relationship was established to support potato growers' decisions on the usefulness of applying the remaining $30 \% \mathrm{~N}$. This required a crop $\mathrm{N}$ status (CNS) assessment in the fertilized field and within a small, untreated area (zero- $\mathrm{N}$ for reference). The strategy developed is economically feasible, easy to operate, and validated for several potato varieties. It also gives the grower the possibility of improving $\mathbf{N}$ use efficiency (NUE). Several tools to assess CNS have been investigated, or are currently being investigated, at the Walloon Agricultural Research Center in Gembloux, Belgium (CRA-W) for integration into this strategy. All the tools are evaluated for four main characteristics: measurement accuracy and precision, sensitivity to $\mathrm{N}$, specificity to $\mathrm{N}$, and feasibility. There are invasive or noninvasive tools. The use of a chlorophyll meter (CM) has been currently developed in the DSS. Current CRA-W research is investigating the potential of crop light reflectance as an indicator of CNS (ground-based radiometers for near remote sensing and satellite multispectral imagery for spatial remote sensing).

$\mathrm{I}$ mproving NUE is important for potato crops because of their relatively poor ability to take up available soil $\mathrm{N}$. Either excess $\mathrm{N}$ or $\mathrm{N}$ deficiency can have detrimental effects on yield, tuber quality, and the environment. However, potato producers in developed countries are under increasing pressure to maintain profitability within new environmental constraints, such as the European Union (EU) nitrates directive 91/ 676/EEC (EU, 1991), the EU water framework directive 2000/60/EC (EU, 2000), and the recent increases in $\mathrm{N}$ fertilizer prices that should encourage more careful input management.

It is therefore essential to develop tools and strategies for potato

Walloon Agricultural Research Centre, Productions and sectors Department, 4 rue du Bordia, 5030 Gembloux, Belgium

This paper was part of the workshop "Improvement in Nitrogen and Water Use Efficiency: Interest of Assessment Tools" held 16 Sept. 2008 at the European Society for Agronomy Congress, Bologna, Italy.

${ }^{1}$ Corresponding author. E-mail: goffart@cra.wallonie. be. farmers that help them apply the right amount of $\mathrm{N}$ at the right time in the right place. Splitting mineral N fertilizer applications is a suitable approach for matching $\mathrm{N}$ need and supply in a dynamic way (Vos and MacKerron, 2000). In-season crop $\mathrm{N}$ monitoring methods for assessing CNS are therefore required to support such strategies. These methods need, however, to have four main characteristics: measurement accuracy and precision (meaning that the measurements related to CNS are near the true value and also repeatable), sensitivity to CNS (meaning that early detection of deficiency in CNS should be possible to still be able to add useful supplemental $\mathrm{N}$ for crop growth), specificity to CNS (meaning that the measurements should ideally be exclusively related to $\mathrm{N}$ supply and to plant $\mathrm{N}$ concentration without interference from other external factors), and feasibility (meaning that if a wider use of the tool by farmers or consultants as a guide to supplemental $\mathrm{N}$ fertilizer application is desirable, it should be easy to employ, cheap, and fast to provide results).

This article presents a summary of a DSS developed by the Walloon Agricultural Research Center in Gembloux, Belgium, for the potato crop, and aimed at improving $\mathrm{N}$ supply management and NUE, together with a short review of existing tools and those currently being investigated for assessing potato CNS. The detailed information of this review can be found in Goffart and Olivier (2004), Goffart et al. $(2005,2008)$, and Olivier et al. (2006).

\section{Presentation of a DSS for $\mathbf{N}$ fertilization management of potato crops}

The development of a DSS for $\mathrm{N}$ fertilization management was based on the combination of a field-scale $\mathrm{N}$ recommendation rate set in terms of the $\mathrm{N}$ budget and of crop $\mathrm{N}$ monitoring (Goffart and Olivier 2004). Figure 1 summarizes the DSS steps. The recommended $\mathrm{N}$ rate is given using Azobil/Azofert software (Machet et al., 2007), a provisional balance-based model applied at a specific field scale at the start of the growing season and developed in northern France by the Institut National de la Recherche Agronomique in Laon. It takes into account the crop $\mathrm{N}$ requirement in relation to the forecasted yield, soil mineral $\mathrm{N}$ supply measured near planting time, and an estimate of soil mineral $\mathrm{N}$ supply during the forthcoming growing season. The application of only $70 \%$ of the recommended $\mathrm{N}$ rate allows a decision to be made on the need to apply the remaining 30\% through in-season crop $\mathrm{N}$ monitoring to assess CNS, with the help of relative values of a CM [model Hydro Ntester (HNT); Yara, Oslo, Norway]. To determine CNS, at 20-50 DAE, two different types of $\mathrm{CM}$ readings

\begin{tabular}{llll}
\hline $\begin{array}{l}\text { Units } \\
\begin{array}{l}\text { To convert U.S. to SI, } \\
\text { multiply by }\end{array}\end{array}$ & U.S. unit & SI unit & $\begin{array}{l}\text { To convert SI to U.S., } \\
\text { multiply by }\end{array}$ \\
\hline 0.3048 & $\mathrm{ft}$ & $\mathrm{m}$ & 3.2808 \\
0.0929 & $\mathrm{ft}^{2}$ & $\mathrm{~m}^{2}$ & 10.7639
\end{tabular}


are required in the field: one in a within-field zero- $\mathrm{N}$ reference plot, another in a homogeneous and representative part of the fertilized field. The established decision rule on the need for supplemental $\mathrm{N}$ is as follows (Olivier et al., 2006):

$$
\begin{gathered}
\mathrm{HNT}_{70}-\mathrm{HNT}_{0}>\mathrm{N}_{70} \times \\
\text { varietal coefficient, }
\end{gathered}
$$

where $\mathrm{HNT}_{70}$ is the $\mathrm{CM}$ reading (mean of 30 readings) in the field receiving $70 \%$ of the recommended $\mathrm{N}$ rate, $\mathrm{HNT}_{0}$ is the $\mathrm{CM}$ reading (mean of 30 readings) in the zero- $\mathrm{N}$ reference plot, $\mathrm{N}_{70}$ is the applied $\mathrm{N}$ rate representing $70 \%$ of the recommended $\mathrm{N}$ rate, and the varietal $\mathrm{co}^{-}$ efficient is the coefficient link to the cropped potato variety (e.g., 0.5 for 'Bintje').

The use of the DSS was validated in Belgium at 40 experimental sites out of 42 , using the variety Bintje, from 1997 to 2007 (Table 1). The decision was validated taking into account at harvest four parameters influenced by $\mathrm{N}$ : total yield, percentage in large size tubers, tuber dry matter content, and residual mineral $\mathrm{N}$ in the soil. The validation of the decision to apply or not the remaining supplemental $30 \% \mathrm{~N}$ was based on the combination of these four effects (Olivier et al., 2006). Supplemental N was required in $65 \%$ of the situations, meaning that $30 \%$ of the provisional recommended $\mathrm{N}$ rate could be saved in $35 \%$ of the fields. The DSS also led to improved NUE through N saving or applying supplemental $\mathrm{N}$ fertilizer (Goffart et al., 2005).

\section{Methods used for assessing potato CNS}

In the DSS, the assessment of leaf chlorophyll concentration through the chlorophyll index with a CM was selected to assess CNS. However, potato $\mathrm{N}$ monitoring for $\mathrm{CNS}$ assessment can be operated at different scales: plant tissues, leaf, whole plant and canopy (Table 2).

The commonly used plant tissue methods, which require invasive sampling of the plant or plant parts, are extensively reviewed by Haase et al. (2000). These are Kjeldhal digestion, Dumas combustion, and near-IR spectroscopy analysis. Ion-specific potentiometry (nitrate-specific electrodes) or nitrate test strips combined with a

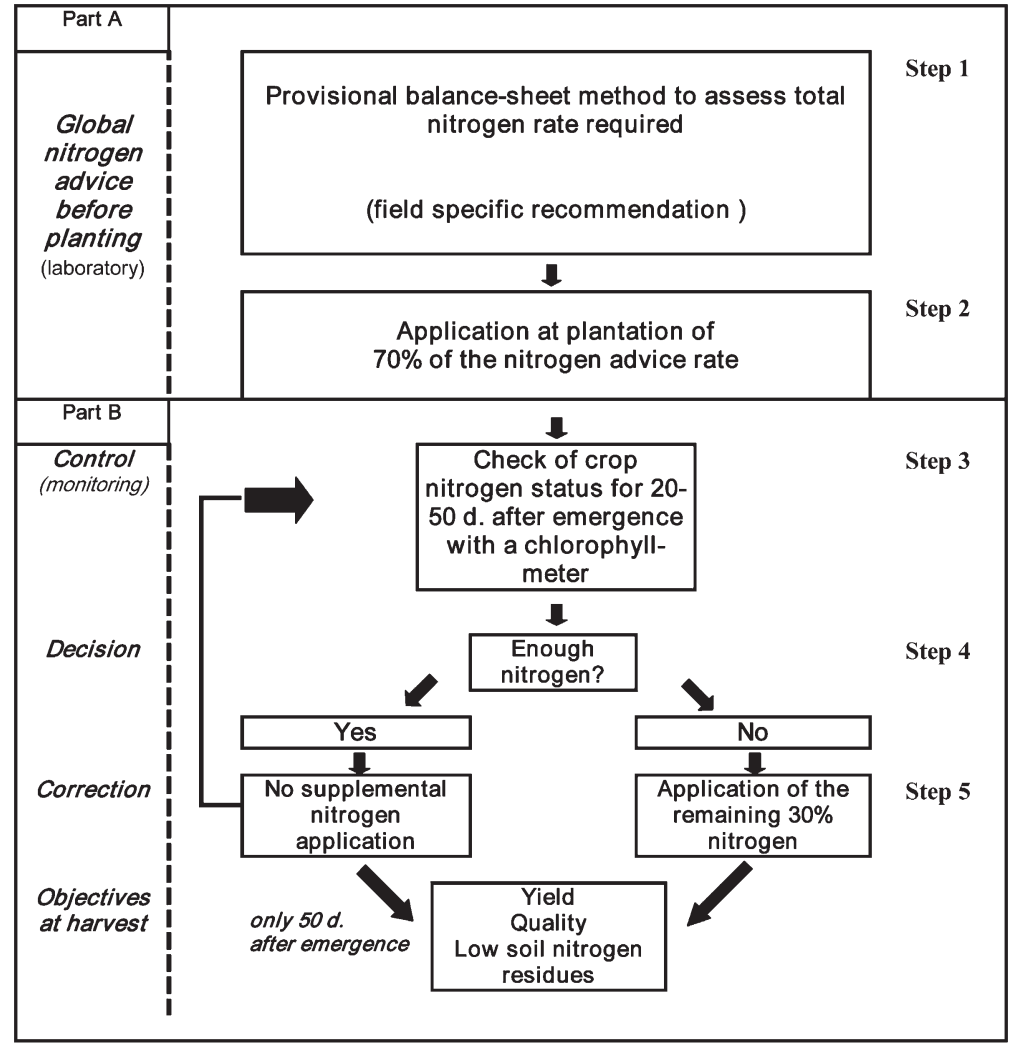

Fig. 1. Steps in the Walloon Agricultural Research Center (Gembloux, Belgium) decision support system for managing the nitrogen fertilization of a potato crop at field scale.

Table 1. Validation of the Hydro N-tester (Yara, Oslo, Norway) chlorophyll meter-based decision support system in 42 situations tested in Belgium with the potato variety Bintje from 1997 to 2007.

\begin{tabular}{lccc}
\hline & $\begin{array}{c}\text { Supplemental } \\
\text { nitrogen useful } \\
\text { (no. of situations) }\end{array}$ & $\begin{array}{c}\text { Supplemental } \\
\text { nitrogen useless } \\
\text { (no. of situations) }\end{array}$ & $\begin{array}{c}\text { Total (no. of } \\
\text { situations) }\end{array}$ \\
\hline Good decision & 27 & 13 & 40 \\
Wrong decision & 1 & 1 & 2 \\
Total & 28 & 14 & $42(95 \%$ validation) \\
\hline
\end{tabular}

reflectometer are used to determine the petiole sap nitrate concentration (PSNC), considered to be an indicator of potato CNS. Apart from these two last methods, methods based on plant tissue analysis are generally expensive, labor intensive, and not suitable for infield monitoring. The PSNC test was developed by scientists in the United States (e.g., Gardner and Jones, 1975; Williams and Maier, 1990), who showed that petiole nitrate concentration expressed on a dry matter basis is a reliable index of the current CNS of potato and a sensitive indicator of $\mathrm{N}$ uptake activity throughout the growing season. Other researchers developed a faster test using the nitrate concentration of the petiole sap (e.g.,
Errebhi et al., 1998). In Europe, the PSNC test was scrutinized by several scientists (e.g., Olivier et al., 1999; Olivier and Goffart 2002; Van Loon et al., 1987). A critical assessment of the PSNC test revealed several weaknesses (MacKerron et al., 1995).

At the leaf or plant scale, several noninvasive methods reviewed by Booij et al. (2000) are available or have been studied (e.g., CMs, chroma meters, chlorophyll fluorescence). The most commonly used near sensing method is based on taking measurements with a CM device that can relate to leaf chlorophyll concentration. A very good and comprehensive review on the use and potential of CM devices [HNT and model SPAD 502 (Minolta, 
Table 2. Most commercially available methods or methods still being investigated for assessing potato crop nitrogen status.

\begin{tabular}{ll}
\hline Measured characteristics & Related techniques $^{\mathbf{z}}$ \\
\hline Petiole sap nitrate concentration & Nitrate specific electrodes \\
Leaf chlorophyll concentration & Nitrate test strips + reflectometer \\
& Chlorophyll meters: SPAD 502, Hydro \\
Leaf chlorophyll fluorescence and & N-tester (near sensing) \\
polyphenolic compounds & Dualex (near sensing), Multiplex \\
absorbance & (near remote sensing) \\
Crop light reflectance & \\
& Multispectral passive sensors: Cropscan, \\
& Grande Paroisse Azote (ground-based \\
& hand-held radiometer) \\
Multispectral active sensors: N-sensor, \\
GreenSeeker, Crop Circle \\
(ground-based remote sensing) \\
Aerial photography (airborne remote \\
sensing) \\
Satellite image (space-based remote \\
sensing)
\end{tabular}

${ }^{2}$ SPAD 502 (Minolta, Osaka, Japan), Hydro N-tester and N-sensor (Yara, Oslo, Norway), Dualex and Multiplex (Force-A, Paris, France), Cropscan (Cropscan, Rochester, MN), Grande Paroisse Azote (AZF-Europe Sol, Toulouse, France), GreenSeeker (NTech Industries, Ukiah, CA), and Crop Circle (Holland Scientific, Lincoln, NE).

Osaka, Japan)] for assessing the potato CNS was provided by Gianquinto et al. (2004). Leaf chlorophyll fluorescencebased methods are also being investigated for crop $\mathrm{N}$ monitoring (Tremblay, 2004). These methods are based on leaf chlorophyll fluorescence induced by ultraviolet radiation and visible radiation and on measurements of the absorbance of ultraviolet wavelength by epidermal leaf polyphenolic compounds (Campbell et al., 2007). Currently being investigated at CRA-W, these methods have a potentially higher sensitivity to CNS because a change in polyphenolics concentration (flavonoïds) related to the CNS, and therefore fluorescence, can be detected before chlorophyll concentration and leaf area index (LAI) are modified (Cartelat et al., 2005). Recently, the noninvasive and hand-held Dualex and Multiplex devices (Force-A, Paris, France) were developed for assessing CNS. They were investigated for the assessment of corn $\mathrm{N}$ status by Tremblay et al. (2007) and Zhang and Tremblay (2010), and they are currently being investigated at CRA-W for the assessment of potato CNS.

At the canopy scale, most of the usable methods for crop monitoring are noninvasive, relying on measurements of light transmitted below the canopy or reflected above it. They belong to the remote sensing methodology (based on spectral canopy properties) that can be operated at different spatial scales: ground-based, airborne, or space-based (Hatfield et al., 2008; Jongschaap, 2006; Tremblay, 2004). They all seek to estimate canopy structure parameters, mainly LAI, based on the knowledge that plant N, leaf chlorophyll, and LAI are strongly related variables (Lemaire, 1997). Common tools being investigated for ground-based remote sensing for potato crops include the Cropscan field hand-held passive radiometer system (Cropscan, Rochester, $\mathrm{MN}$ ) first tested on potatoes in Europe by Booij and Uenk (2004), but still under investigation at CRA-W. It also includes the $\mathrm{N}$-sensor (Yara) tested and developed in Europe (a canopy reflection-based system with four tractor-mounted passive or active sensors; Link et al., 2002) and the Greenseeker (NTech Industries, Ukiah, CA, or Crop Circle (Holland Scientific, Lincoln, NE) with active sensor tested in the United States (more information of both devices can be found in Samborski et al., 2009). Using leaf or canopy reflectance at different wavelength bands allows vegetation indices (VIs) to be calculated and used for CNS assessment. Ground-based canopy light reflectance readings with ground-based Cropscan radiometer have the advantage of integrating a larger sampling area at each reading and involving less labor than the use of the CM. However, particularly for the potato crop, VIs also have to incorporate the fact that canopy spectral responses are modified by the proportion of vegetation cover and exposed soil and that the architectural arrangement of stems and leaves varies with plant growth. Specific VIs such as the soiladjusted vegetation index [SAVI (Huete, 1988)], the optimized SAVI (Rondeaux et al., 1996), and the transformed SAVI (Wiegand et al., 1991 ) have been developed to reduce or remove background soil effect. However, hand-held ground-based radiometers are generally not easy to use as they were intended for scientific use rather than by growers. Some easier to use commercial devices measure crop light reflectance at similar wavelength bands (red and near-IR) used for the CM. This is the case with the hand-held equipment known as Grande Paroisse Azote (GPN; AZFEurope Sol, Toulouse, France), a hand-held ground-based radiometer using a 1 -m-long probe equipped at its end with a sensing head, designed for easy and quick use in the field. The drawback of this device is that its sensitivity is slightly lower than that of the CM [HNT and SPAD 502 (J.P. Goffart, unpublished data)]. Its major advantage is its feasibility because it can provide quick readings, while walking through the canopy.

The potential of the most commonly available methods tested at CRA-W in the last decade for assessing potato CNS is outlined in Table 3 .

Based on canopy reflectance properties as ground-based near remote sensing, airborne and space-based remote sensing depend mainly on acquiring aerial and satellite numerical images, either at the field or regional scale. Airborne and space-based remote sensing technologies are fast developing fields of investigation for platforms (manned or unmanned crafts and airplanes, and satellite platforms) and for radiometric, spectral, spatial, and temporal resolutions. The use of high-spatial resolution satellite sensors such as the Satellite Pour l'Observation de la Terre-5 [SPOT-5 (10 m for multispectral image)] also is currently being investigated at CRA-W (Goffart et al., 2010) for assessing the potato CNS. 
Table 3. Summary of the potential of the most commonly available methods for assessing potato crop nitrogen status (CNS) evaluated at Walloon Agricultural Research Center (Gembloux, Belgium)

\begin{tabular}{|c|c|c|c|c|}
\hline & \multicolumn{4}{|c|}{ CNS assessment method ${ }^{\mathrm{z}}$} \\
\hline & PSNC & SPAD/HNT & GPN & Cropscan \\
\hline $\begin{array}{l}\text { Accuracy/ } \\
\text { precision }\end{array}$ & - - & ++ & ++ & ++ \\
\hline Sensitivity & +++ & $\begin{array}{l}\quad++ \\
\text { But restricted to } \\
\text { comparison of } \\
\text { nonfertilized vs. } \\
\text { fertilized plots }\end{array}$ & $\begin{array}{l}\stackrel{++}{\text { But restricted to }} \\
\text { comparison of } \\
\text { nonfertilized vs. } \\
\text { fertilized plots }\end{array}$ & $\begin{array}{l}\text { Calculation of large } \\
\text { range of vegetation } \\
\text { indices available } \\
\text { allowing increasing } \\
\text { sensitivity }\end{array}$ \\
\hline Specificity & $\ldots$ & $-\ldots$ & $-\ldots$ & $-\ldots$ \\
\hline Feasibility & - & ++ & +++ & ++ \\
\hline
\end{tabular}

\section{Conclusion and perspectives}

The assessment of in-season potato CNS, together with split fertilizer application is better suited to $\mathrm{N}$ crop need and $\mathrm{N}$ supply. A reliable DSS combining $\mathrm{N}$ balance models with tools developed for in-season CNS monitoring has been developed. The CRA-W chlorophyll-based DSS is a good example of a practical approach for growers. Its main limitation is the accurate assessment of the amount of $\mathrm{N}$ to be supplemented when observations indicate that a deficiency is present or imminent. However, if in the future, methods such as fast leaf chlorophyll assessment are combined with improved potato growth simulation models, they will probably be able to meet this challenge.

From the different methods for potato CNS assessment developed over the years, remotely sensed above-crop reflectance measurements are potentially the most promising, mainly because they can integrate canopy depth and larger canopy areas better than other methods. Obtaining detailed and spatially specific temporal information using methods such as the PSNC test or the CM test is difficult, labor-intensive, and expensive. In addition, airborne or space-based remote sensing imagery is not limited by sampling interval or geostatistical interpolation, as is the case with grid-sampled soil or plant test data. However, its feasibility, accuracy, and sensitivity require more in-depth research on the best platforms to use to collect information (ground-based, airborne, or spacebased remote sensing).

\section{Literature cited}

Booij, R., J.L. Valenzuela, and C. Aguilera. 2000. Determination of crop nitrogen status using non-invasive methods, $p$. 72-82. In: A.J. Haverkort and D.K.L. MacKerron (eds.). Management of nitrogen and water in potato production. Wageningen Academic Publishers, Wageningen, The Netherlands.

Booij, R. and D. Uenk. 2004. Cropreflection-based DSS for supplemental nitrogen dressings in potato production, p. 47-53. In: A.J. Haverkort and D.K.L. MacKerron (eds.). Decision support systems in potato production-Bringing models to practice. Wageningen Academic Publishers, Wageningen, the Netherlands.

Campbell, P.K.E., E.M. Middleton, J.E. McMurtry, L.A. Corp, and E.W. Chapelle. 2007. Assessment of vegetation stress using reflectance or fluorescence measurements. J. Environ. Qual. 36:832-845.

Cartelat, A., Z.G. Cerovic, Y. Goulas, S. Meyer, C. Lelarge, J.L. Prioul, A. Barbottin, M.H. Jeuffroy, P. Gate, G. Agati, and I. Moya. 2005. Optically assessed contents of leaf polyphenolics and chlorophyll as indicators of nitrogen deficiency in wheat (Triticum aestivum L.). Field Crops Res. 91:35-49.

Errebhi, M., C.J. Rosen, and D.E. Birong. 1998. Calibration of a petiole sap nitrate test for irrigated Russet Burbank potato. Commun. Soil Sci. Plant Anal. 29:23-35.

European Union. 1991. Council Directive 91/676.EEC of 12 Dec. 1991 con- cerning the protection of waters against pollution caused by nitrates from agricultural sources. European Commission Offic. J. L375:1-8.

European Union. 2000. Directive 2000/ $60 / \mathrm{EC}$ of the European Parliament and of the Council of 23 Oct. 2000 establishing a framework for Community action in the field of water policy. European Commission Offic. J. L327:1-73.

Gardner, B.R. and J.P. Jones. 1975. Petiole analysis and the nitrogen fertilization of Russet Burbank potatoes. Amer. Potato J. 52:195-200.

Gianquinto, G., J.P. Goffart, M. Olivier, G. Guarda, M. Colauzzi, L. Dalla Costa, G. Delle Vedove, J. Vos, and D.K.L. MacKerron. 2004. The use of hand-held chlorophyll meters as a tool to assess the nitrogen status and to guide nitrogen fertilization of potato crop. Potato Res. 47: 35-80.

Goffart, J.P. and M. Olivier. 2004. Management of $\mathrm{N}$-fertilization of the potato crop using total $\mathrm{N}$-advice software and inseason chlorophyll meter measurements, p. 68-83. In: A.J. Haverkort and D.K.L. MacKerron (eds.). Decision support systems in potato production-Bringing models to practice. Wageningen Academic Publishers, Wageningen, The Netherlands.

Goffart, J.P., M. Olivier, and J.P. Destain. 2005. Presentation of a decision support system for nitrogen management in potato production to improve the use of resources, p. 134-142. In A.J. Haverkort and P.C. Struik (eds.). Potato in progressScience meets practice. Wageningen Academic Publishers, Wageningen, The Netherlands.

Goffart, J.P., M. Olivier, and F. Frankinet. 2008. Potato crop nitrogen status assessment to improve $\mathrm{N}$ fertilization management and efficiency: Past-present-future. Potato Res. 51:355-383.

Goffart, J.P., L. Van Den Wyngaert, D. Buffet, A. Leonard, and P. Defourny. 2010. SPOT 5 multispectral data potentialities to monitor potato crop nitrogen status at specific field scale. 10th Intl. Conf. Precision Agr., p. 65. (Abstr.).

Haase, N.U., J.P. Goffart, D.K.L. MacKerron, and M.W. Young. 2000. Determination of crop nitrogen status using invasive methods, p. 55-71. In: A.J. Haverkort and D.K.L. MacKerron (eds.). Management of nitrogen and water in potato production. Wageningen Academic Publishers, Wageningen, The Netherlands.

Hatfield, J.L., A.A. Gitelson, J.S. Schepers, and C.L. Walthall. 2008. Application of 
spectral remote sensing for agronomic decisions. Agron. J. 100:S117-S131.

Huete, A.R. 1988. A soils-adjusted vegetation index (SAVI). Remote Sens. Environ. 25:295-309.

Jongschaap, R.E.E. 2006. Integrating crop growth simulation and remote sensing to improve resource use efficiency in farming systems. Wageningen Univ., Wageningen, The Netherlands, PhD Thesis.

Lemaire, G. 1997. Diagnosis of the nitrogen status in crops. Springer Verlag, Berlin, Heidelberg.

Link, A., M. Panitzki, S. Reusch, and J. Lammel. 2002. Hydro-N-Sensor: Tractormounted remote sensing for variable nitrogen fertilization, p. 1012-1018. In: P.C. Robert (ed.). Precision agriculture. Proc. 6th Intl. Conf. Precision Agr. Other Precision Res. Mgt. Minneapolis, MN.

Machet, J.M., P. Dubrulle, N. Damay, R. Duval, S. Recous, and B. Mary. 2007. Azofert: A new decision support tool for fertilizer nitrogen advice based on a dynamic version of the predictive balance sheet method. Proc. 16th Intl Symp. Intl. Sci. Centre Fert. (CIEC). p. 322-328.

MacKerron, D.K.L., W. Young, and H.V. Davies. 1995. A critical assessment of the value of petiole sap analysis in optimising the nitrogen nutrition of the potato crop. Plant Soil 172:247-260.

Olivier, M. and J.P. Goffart. 2002. Chlorophyll meter used as decision tool to manage nitrogen fertilization in potato crop. European Assn. Potato Res. 15th Triennial Conf. p. 68. (Abstr.).

Olivier, M., J.P. Goffart, G. Sinnaeve, and P. Dardenne. 1999. Evaluation of invasive and non-invasive methods to assess the nitrogen status of the potato crop in the course of the season. European Assn. Potato Res. 14th Triennial Conf. p. 134-135. (Abstr.).

Olivier, M., J.P. Goffart, and J.F. Ledent. 2006. Threshold values for chlorophyll meter as decision tool for nitrogen management of potato. Agron. J. 98:496-506.

Rondeaux, G., M. Steven, and F. Baret. 1996. Optimization of soil-adjusted vegetation indices. Remote Sens. Environ. 55: 95-107.

Samborski, S., N. Tremblay, and E. Fallon. 2009. Strategies to make use of plant sensors-based diagnostic information for nitrogen recommendations. Agron. J. 101:800-816.

Tremblay, N. 2004. Determining nitrogen requirements from crop characteristics. Recent Res. Dev. Agron. Hort. 1: 157-182.
Tremblay, N., Z. Wang, and C. Bélec. 2007. Evaluation of the Dualex for the assessment of corn nitrogen status. J. Plant Nutr. 30:1355-1369.

Van Loon, C.D., J.H.G. Slangen, and J.H. Houwing. 1987. Nitrate content of leaf petioles as a guide to optimization of $\mathrm{N}$-fertilization of ware potatoes. European Assn. Potato Res. 10th Triennial Conf. p. 146-147. (Abstr.).

Vos, J. and D.K.L. MacKerron. 2000. Basic concepts of the management of supply of nitrogen and water in potato production, p. 15-33. In: A.J. Haverkort and D.K.L. MacKerron (eds.). Management of nitrogen and water in potato production. Wageningen Academic Publishers, Wageningen, The Netherlands.

Wiegand, C.L., A.J. Richardson, D.E. Escobar, and A.H. Gerbermann. 1991. Vegetation indices in crop assessments. Remote Sens. Environ. 35:105-119.

Williams, C.M.J. and N.A. Maier. 1990. Determination of the nitrogen status of irrigated potato crops. I. Critical nutrient ranges for nitrate-nitrogen in petioles. J. Plant Nutr. 13:971-984.

Zhang, Y.P. and N. Tremblay. 2010. Evaluation of the Multiplex fluorescence sensor for the assessment of corn nitrogen status. 10th Intl. Conf. Precision Agr. p. 148. (Abstr.). 